\title{
The relationship of ischemia-modified albumin levels to disease activity scores and HLA-B27 in patients with ankylosing spondylitis
}

\author{
(1) Filiz Meryem Sertpoyraz, ${ }^{1}$ ㄴ) Ayfer Colak, ${ }^{2}$ (i) Aylin Dikici, ${ }^{1}$ (i) Nihan Erdinc Gunduz, ${ }^{1}$ \\ (D) Merve Zeytinli Aksit ${ }^{2}$ \\ ${ }^{1}$ Department of Physical Medicine and Rehabilitation, Health Science University Izmir Training and Research Hospital, Izmir, Turkey \\ ${ }^{2}$ Department of Biochemistry, Health Science University Izmir Training and Research Hospital, Izmir, Turkey
}

\begin{abstract}
OBJECTIVE: Recent studies have implicated increased oxidative stress in the pathogenesis of Ankylosing spondylitis (AS). Ischemia-modified albumin (IMA), an altered form of albumin, increases oxidative stress. This study aimed to investigate the relationship between IMA levels and other indicators of disease severity in AS.

METHODS: This study included 63 AS patients and 48 healthy controls. Patients were examined for serum lipid profile, C-reactive protein (CRP), complete blood count, Bath Ankylosing Spondylitis Disease Activity Index, human leukocyte antigen (HLA) B27, and treatment regimen. They were categorized based on disease activity, HLA-B27 status, and the drug treatment and compared for IMA levels.

RESULTS: The patients had significantly higher IMA levels than controls ( $p=0.020)$; among patients, the levels were higher in those with active disease $(p=0.001)$ and positively correlated with the CRP levels. No significant difference was found between the IMA levels of the patients with different HLA-B27 status or treatment method.

CONCLUSION: The IMA levels were higher in patients than controls and further increased in patients with active AS. IMA was associated with disease activity and can be used as an inflammatory marker in AS. More comprehensive future studies with a larger sample size may help understand the relationship in greater detail.

Keywords: Ankylosing spondylitis; disease activity; ischemia-modified albumin.

Cite this article as: Sertpoyraz FM, Colak A, Dikici A, Erdinc Gunduz N, Zeytinli Aksit M. The relationship of ischemia-modified albumin levels to disease activity scores and HLA-B27 in patients with ankylosing spondylitis. North Clin Istanb 2021;8(1):42-48.
\end{abstract}

A nkylosing Spondylitis (AS) is a chronic rheumatic disease that is characterized by inflammatory low back pain, is often accompanied by peripheral arthritis, and has a prevalence of $0.9 \%$ worldwide [1]. AS often affects young men, causing loss of function and deterioration in the quality of life [2]. AS is characterized by the inflammation of the sacroiliac joint, peripheral enthesis, and subchondral bone marrow. The mechanism of pathogenesis has not been fully elucidated; however, sev- eral genes, including human leukocyte antigen (HLA) B27, chronic inflammation caused by intestinal bacteria, cytokines, and oxidative stress, are known to have a role in pathogenesis [3].

In an organism, the rate of formation and elimination of free radicals are at equilibrium, which is called oxidative equilibrium. When the oxidative equilibrium is achieved, free oxygen radicals do not affect the organism; oxidative stress occurs when this balance is uneasy. A se-

Received: November 29, 2019 Accepted: June 08, 2020 Online: November 24, 2020

Correspondence: Filiz Meryem SERTPOYRAZ, MD. Izmir Tepecik Egitim ve Arastirma Hastanesi, Fiziksel Tedavi ve Rehabilitasyon Klinigi, Izmir, Turkey.

Tel: +90 2324696969 - 2405 e-mail: dr.fms70@gmail.com

(c) Copyright 2021 by Istanbul Provincial Directorate of Health - Available online at www.northclinist.com 
vere imbalance between free radical formation and the antioxidant defense mechanism ultimately leads to tissue injury [4].

The findings in the literature showed that oxidative stress has an important role in the pathogenesis of AS, as well as in the pathogenesis of inflammatory diseases, such as rheumatoid arthritis, systemic lupus erythematosus, psoriasis, and Behçet disease [4-6] and that the molecular products of oxidative stress increase in AS $[7,8]$.

Albumin acts as an antioxidant by removing oxidative stress products. Free-radical damage to albumin occurs due to hypoxia, acidosis, and oxidative stress. Thus, the capacity of albumin to bind and remove ions, such as copper, nickel, and cobalt in the $\mathrm{N}$-terminus decreases, and ischemia-modified albumin (IMA) is formed. IMA is considered a biomarker indicating oxidative stress [9].

Although the role of oxidative stress in the pathogenesis of AS has not been fully elucidated, Biasi et al. [10] have shown an abnormally high level of neutrophil migration during the active period of AS and an increased response to reactive oxygen species by circulating neutrophils. Additionally, recent studies have shown that IMA, a product of oxidative stress, has increased concerning inflammation in both rheumatic and non-rheumatic diseases [11-13]. However, studies evaluating the IMA levels in patients with AS are limited.

This study aimed to evaluate the levels of IMA in patients with AS, an inflammatory disease, and to investigate the relationship between the IMA levels and disease activity criteria, such as Bath Ankylosing Spondylitis Disease Activity Index (BASDAI), C-reactive protein (CRP), HLA-B27, and medical treatment. To our knowledge, this study is the first study to evaluate the relationship between the IMA levels and the HLA-B27 and medical therapy.

\section{MATERIALS AND METHODS}

\section{Case-Control Study}

This study was initially planned to include 70 patients who had been diagnosed according to the modified New York criteria and treated in the Health Science University Izmir Tepecik Training and Research Hospital in 2018. Final analyses included 63 patients $(28$ female and 35 male) and 48 healthy controls ( 22 female and 26 male) since five patients were excluded due to cardiac problems and two patients due to having diabetes mellitus.

\section{Highlight key points}

- Ankylosing Spondylitis (AS) is a chronic rheumatic disease that is characterized by inflammatory.

- Ischemia-modified albumin is considered a biomarker indicating oxidative stress.

- Ischemia-modified albumin is associated with disease activity and can be used as an inflammatory marker in AS.

All patients and/or their relatives read the Helsinki Declaration of Patients' Rights and signed an informed consent form. Ethical approval was taken from the local Ethics Committee for this study (Ethics Committee Approval Number: 2018-8-4).

This study included the AS patients diagnosed according to the modified New York criteria and healthy volunteers who were aged 18 or above and signed the informed consent form. Those who did not sign the consent form, had an acute or chronic infection, myocardial infarction, other cardiac problems, diabetes mellitus, liver disease, hypertension, hyperlipidemia, renal failure, ischemic cerebrovascular disease, or history of a non-AS rheumatic disease, smoked, or were obese or pregnant were excluded from this study. Patients with a disease, which -except for AS-may increase the CRP level, were not included in this study.

Medical records were mined for demographic information (age, gender, education, medical treatments, and exercise status) and the BASDAI scores and the HLA-B27 levels at the time of admission.

Serum albumin, IMA, total cholesterol, high-density lipoprotein (HDL-c), low-density lipoprotein (LDL-c), triglycerides, and CRP levels were also evaluated. The HLA-B27 results of 56 patients were obtained from records; they were grouped as positive and negative for this antigen. Disease activity was evaluated with BASDAI, which consists of visual analog scales that question five major AS symptoms: fatigue, spine pain, joint pain/swelling, localized sensitivity, and morning stiffness [14]. Patients with a BASDAI score of $\geq 4$ were considered active AS, those with a score of $<4$ were considered inactive [14].

Initially, patients with AS were compared with healthy controls for CRP, albumin, IMA, cholesterol, triglyceride, HDL-c, and LDL-c. Then, the patients were divided into two groups based on BASDAI scores (active vs. inactive), into two groups based on HLA-B27 (positive vs. negative), or into three groups based on the medical treatment they received (anti-tumor necrosis factor 
(TNF), sulfasalazine, and non-steroid anti-inflammatory drug (NSAID) and were compared.

\section{Laboratory Analysis}

The complete blood count measurement was performed using a Beckman Coulter LH 780 (Olympus Diagnostics, GmbH, Hamburg, Germany) blood count device immediately. Biochemical tests were performed on the same day on the obtained serum samples. For IMA level, serum samples were transferred to Eppendorf tubes and stored at $-80^{\circ} \mathrm{C}$. Serum total cholesterol, triglyceride, HDL-c, and CRP levels were measured using a Beckman Coulter AU 5800 (Olympus Diagnostics, GmbH, Hamburg, Germany) analyzer. The LDL-c levels were calculated with the Friedewald formula.

\section{Ischemia-Modified Albumin}

The IMA levels were determined spectrophotometrically using the method described by Bar-Or et al. [15]. For this, $200 \mu \mathrm{L}$ of venous serum (after 12-hour fasting) was mixed with $50 \mu \mathrm{L}$ cobalt chloride and incubated for 10 minutes. Then, $50 \mu \mathrm{L}$ dithiothreitol was added to fix unbound cobalt and form a colored complex in order to determine the amount of unbound cobalt; the reaction was stopped after two minutes by adding $1 \mathrm{~mL}$ of physiological saline solution. The resulting colored complex was measured with a spectrophotometer at $470 \mathrm{~nm}$ using the same sample without the addition of DTT as blank; results were given as absorbance units [16].

Blood was taken from the cannulated antecubital vein between 08:00 and 09:00 h after 12-h overnight fasting. Blood samples for serum preparation were allowed to clot. Samples were centrifuged for five min at $5000 \mathrm{rpm}$ and serum was separated. The resulting colored complexes were measured by the absorbance at $470 \mathrm{~nm}$ using a spectrophotometer (UV-1800, Shimadzu Corporation, Kyoto, Japan) using the same sample without the addition of DTT as blank; results were given as absorbance units.

\section{Statistical Analysis}

Statistical analyses were performed with the Statistical Package for the Social Sciences 20 (SPSS, SPSS Inc., Chicago, IL, USA). Data were expressed as the meantstandard deviation (SD). Shapiro-Wilk test was used to determine the normal distribution of the data. Chi-square test was used to compare the gender distribution among groups. The independent samples t-test was used for in-
TABLE 1. Demographic data for the patients with AS

\begin{tabular}{|c|c|}
\hline & $\%$ \\
\hline Age, Mean $\pm S D$ (Min.-Max.) & $43.9 \pm 11.7(21-69)$ \\
\hline \multicolumn{2}{|l|}{ Sex } \\
\hline Male & 56 \\
\hline Female & 44 \\
\hline \multicolumn{2}{|l|}{ Education } \\
\hline Non-literate & 3 \\
\hline Primary education & 35 \\
\hline Secondary & 54 \\
\hline University & 8 \\
\hline \multicolumn{2}{|l|}{ Occupation } \\
\hline Housewife & 33 \\
\hline Worker & 54 \\
\hline Retired & 13 \\
\hline \multicolumn{2}{|l|}{ Medical treatment } \\
\hline Not receiving medical treatment & 5 \\
\hline Non-steroid anti-inflammatory drug & 32 \\
\hline Sulfasalazine & 33 \\
\hline Anti-TNF & 30 \\
\hline \multicolumn{2}{|l|}{ Exercise } \\
\hline No & 37 \\
\hline Regular exercise & 30 \\
\hline Irregular exercise & 33 \\
\hline \multicolumn{2}{|l|}{ BASDAI Score } \\
\hline$\geq 4$ & 52 \\
\hline$<4$ & 48 \\
\hline \multicolumn{2}{|l|}{ HLA-B27 status } \\
\hline Positive & 63 \\
\hline Negative & 37 \\
\hline
\end{tabular}

AS: Ankylosing spondylitis; SD: Standard deviation; Min.: Minumum; Max.: Maximum; BASDAI: Bath ankylosing spondylitis disease activity index; HLA: Human leukocyte antigen; TNF: Tumor necrosis factor

ter-group comparisons regarding the parameters with a normal distribution. Mann-Whitney $U$ test was used for other parameters. Pearson correlation test was used for the analysis of the relationships between the data with a normal distribution; otherwise, the Spearman correlation test was used. The statistical significance level was set at $\mathrm{p}<0.05$.

\section{RESULTS}

This study included 63 patients with AS and 48 healthy volunteers. Demographic data for patients with AS are shown in Table 1 . 
TABLE 2. Comparison of the patients and controls

\begin{tabular}{lccc} 
& $\begin{array}{c}\text { Patients } \\
(\mathrm{n}=63) \\
(\text { Mean } \pm S \mathrm{SD})\end{array}$ & $\begin{array}{c}\text { Controls } \\
(\mathrm{n}=48)\end{array}$ & $\mathrm{p}^{*}$ \\
& $($ Mean $\pm \mathrm{SD})$ & \\
\hline Age (year) & $43.9 \pm 11.7$ & $40.3 \pm 10.5$ & 0.900 \\
Gender (Female/Male) & $28 / 35$ & $22 / 26$ & 0.884 \\
Albumin & $4.42 \pm 0.26$ & $4.16 \pm 0.99$ & 0.882 \\
Ischemic modified albumin & $0.442 \pm 0.12$ & $0.388 \pm 0.09$ & $\mathbf{0 . 0 2 0}$ \\
C-reactive protein & $1.21 \pm 1.36$ & $1.00 \pm 0.96$ & 0.339 \\
Cholesterol & $206 \pm 53$ & $209 \pm 54$ & 0.812 \\
Triglyceride & $176 \pm 151$ & $146 \pm 70$ & 0.707 \\
HDL-c & $48 \pm 15$ & $48 \pm 11$ & 0.419 \\
LDL-c & $135 \pm 57$ & $131 \pm 46$ & 0.988 \\
\hline
\end{tabular}

SD: Standard deviation; HDL: High-density lipoprotein; LDL: Low-density lipoprotein; *: $p<0.05$ was considered statistically significant (in bold typeface).

TABLE 3. Comparison of the patients with active and inactive AS

\begin{tabular}{lccc} 
& $\begin{array}{c}\text { Active } \\
(\mathrm{n}=33) \\
(\text { Mean } \pm S D)\end{array}$ & $\begin{array}{c}\text { Inactive } \\
(\mathrm{n}=30)\end{array}$ & $\mathrm{p}^{*}$ \\
$($ Mean $\pm \mathrm{SD})$ & \\
\hline C-reactive protein & $1.59 \pm 1.70$ & $0.77 \pm 0.65$ & $\mathbf{0 . 0 0 3}$ \\
Ischemic modified albumin & $0.511 \pm 0.074$ & $0.376 \pm 0.109$ & $\mathbf{0 . 0 0 1}$ \\
Total cholesterol & $212 \pm 51$ & $205 \pm 40$ & 0.561 \\
Triglyceride & $193 \pm 19$ & $157 \pm 84$ & 0.806 \\
HDL-cholesterol & $48 \pm 18$ & $47 \pm 11$ & 0.696 \\
LDL-cholesterol & $141 \pm 74$ & $127 \pm 28$ & 0.707 \\
\hline
\end{tabular}

AS: Ankylosing spondylitis; SD: Standard deviation; HDL: High-density lipoprotein; LDL: Low-density lipoprotein; *: $p<0.05$ was considered statistically significant (in bold typeface).

No significant difference was found between the AS patients and controls concerning age and gender distribution ( $p=0.900$ and $p=0.884)$. Biochemical findings are shown in Table 2.

The IMA (absorbance) values were higher in the AS patients compared to those of the controls $(p=0.020)$.

The mean CRP value of the AS patients was higher than that of the controls, but the difference was not statistically significant $(\mathrm{p}=0.339)$.

The BASDAI score was high (active AS) in 33 (52\%) of the patients with AS; 30 (48\%) of them were considered to have inactive AS. The CRP and IMA levels were found significantly higher in patients with active disease $(p=0.003$ and $p=0.001$, respectively). A significant positive correlation was found between the CRP and IMA values $(\mathrm{p}=0.001, \mathrm{r}=0.320)$ as shown in Table 3 .

The BASDAI scores were higher among the patients who were positive for HLA-B27 compared to those who were negative, but the difference was not statistically significant $(p=0.832)$. Similarly, the IMA levels were higher among the patients who were positive for HLA-B27, albeit not statistically significant $(\mathrm{p}=0.776)$.

No significant difference was found between the patients receiving anti-TNF, sulfasalazine, or NSAIDs regarding the IMA levels $(p=0.335)$.

\section{DISCUSSION}

A significant difference was found between the IMA levels in patients with AS and healthy controls. The IMA and CRP levels in the patients with active AS were higher than those with inactive AS. In patients with AS, the IMA levels had a positive correlation with the disease activity criteria, BASDAI and CRP. No significant difference was found between the IMA levels in HLA-B27 positive and negative groups and the groups receiving different medical treatments.

The disturbance of the oxidative balance happens to an increase in free radicals, the products of oxidative stress [15]. They also attack proteins, lipids, and carbohydrates, causing modifications in these structures at the cellular level. Lipids are among the most sensitive molecules; disruptions in cell membrane lipids due to oxidative stress are the most important cause of tissue damage [17-19].

The levels of IMA increased in diseases involving ischemia and hypoxia, such as myocardial infarction, pulmonary embolism, cerebrovascular ischemic diseases, end-stage cancers, systemic sclerosis, and diabetes mellitus and in disease involving inflammation, such as obesity, multiple sclerosis, psoriasis, and inflammatory rheumatic diseases [20-23]. Inflammation increases the rate of proinflammatory cytokines, such as TNF- $\alpha$ and interleukin- $1 \beta$, which leads to tissue damage by increasing the rate of free radical formation. Increased IMA levels were found in rheumatoid arthritis and Behçet disease [24, 25]. On the other hand, a study on the inflammatory parameters, IMA levels, and their relationship with atherosclerosis in Sjögren syndrome, an inflammatory rheumatic 
disease, found no relationship between the IMA levels and inflammatory parameters [26].

In our study, the IMA levels were higher in patients with AS than healthy controls. Consistent with our results, other recent studies have also found increased IMA levels in patients with AS than healthy controls [13]. A recent study has found that the oxidant levels were higher and the antioxidant levels were lower in the AS patients compared to healthy controls [27].

Wang et al. [28] have investigated bone markers, bone mineral density, and oxidation status in AS patients. They found increased inflammatory markers, bone destruction products, and oxidation products in patients with active disease and suggested that oxidative stress plays an important role in the pathogenesis of AS and also influences bone mineral density.

The IMA levels in AS patients with active disease were higher than those with inactive disease. In a similar study, Türkön et al. [13] investigated the relationship between serum IMA levels and the oxidant/antioxidant ratio in patients with AS. IMA and IMAR positively correlated with BASDAI, Bath Ankylosing Spondylitis Functional Index, Bath Ankylosing Spondylitis Metrology Index, ASDAS, and CRP, which suggested that increased IMA levels are related to the pathogenesis and activity of the disease.

The CRP levels are frequently used to determine the degree of inflammation and to assess the acute phase response in rheumatic diseases [29, 30]. CRP is a sensitive indicator of acute inflammation in patients with AS. The synthesis of CRP occurs in the liver through the action of cytokines, mainly IL- 6 , which is secreted from the inflamed tissue. It has been shown that serum IL- 6 levels were higher in patients with AS than healthy individuals [31]. BASDAI, CRP, and the Ankylosing Spondylitis Disease Activity Score are frequently used in the evaluation of disease activity and in determining the treatment [16]. In our study, BASDAI and CRP were used to assess disease activity. The CRP and IMA levels were high in patients with active AS, and there was a positive correlation between them. Consistent with our study, it was previously found that high CRP values were associated with radiological changes and sacroiliac joint inflammation and also correlated with the BASDAI scores [31].

Oxidative stress products are increased during the active period of AS, which increase the levels of TNF and inflammatory cytokines IL- $6,-17$, and -23 , initiating the inflammation and causing tissue damage [32]. In this process, the increased CRP might be considered an indicator of inflammation and high IMA an indicator of oxidative stress. Karataş et al. [33] found that the IMA levels were higher in the acute period and correlated with acute phase reactants in patients with acute rheumatic fever and that the levels were similar to healthy controls in the chronic period. IMA levels might be associated with acute inflammation. Among patients with Behcet's disease, the IMA levels were found to increase in those with active disease and vascular involvement [34].

HLA-B27 is an allele for the B locus encoding major histocompatibility complex class I molecules and is the best known genetic marker for AS. Misfolding of HLA-B27 leads to the excessive stimulation of IL23, which leads to activation of $\mathrm{T}$ helper cells [35]. In AS, $72-90 \%$ of patients are positive for HLA-B27 [36]. In our study, $63 \%$ of the patients were positive for HLA-B27. No significant relationship was found between IMA levels and HLA-B27 positivity in patients. To our knowledge, there is not any study evaluating the oxidative status in HLA-B27 positive and negative patients in the literature.

Studies investigating the effect of drugs on oxidative stress are limited. In our study, no difference was found between the IMA levels of patients receiving anti-TNF, sulfasalazine, or NSAID treatment. Possible mechanisms of action for 5-aminosalicylic acid -the active metabolite of sulfasalazine-include the inhibition of natural killer cells, antibody synthesis, cyclooxygenase and lipoxygenase pathways, and neutrophil functions and scavenging oxygen free radicals. Kocabaş et al. [37] did not find a significant difference between the oxidant/antioxidant levels in patients with AS who do or do not receive sulfasalazine treatment.

TNF- $\alpha$ is an inflammatory cytokine released from monocytes and macrophages. TNF- $\alpha$ stimulates chondrocytes and increases the release of oxygen free radicals and nitric oxide. The TNF- $\alpha$ levels provide information about the inflammatory process [38]. In AS, the increase in the activation of neutrophils is known to trigger oxidative stress. Anti-TNF treatments are effective on both TNF- $\alpha$ and neutrophils. The treatment is known to decrease calcium flow through the cation channel modulation and to decrease apoptosis and oxidative stress. Kageyasa et al. [39] reported that infliximab, an anti-TNF agent, inhibited the oxidative DNA damage and lipid peroxidation in patients with rheumatoid arthritis and acted as an antioxidant. In a study of the effects of anti-TNF agents and NSAIDs on oxidative stress in pa- 
tients with AS, the former was found to alleviate oxidative stress while the latter had limited effect [40].

Limitations of this study include small sample size, lack of consideration of other markers for oxidant/antioxidant status or other disease activity scales, such as BASFI and BASMI.

The duration and details of medical treatments were also not questioned.

In conclusion, our study has shown that the levels of IMA and CRP, two oxidative stress markers, were significantly higher in patients with active AS than healthy controls or patients with inactive AS. There was no difference in the IMA levels of the patients receiving different medical treatments or of those carrying the HLA-B27 allele or not. IMA is associated with disease activity and can be used as an inflammatory marker in AS. More comprehensive future studies with a larger sample size may help understand the relationship in greater detail.

Ethics Committee Approval: The Health Science University Izmir Training and Research Hospital Clinical Research Ethics Committee granted approval for this study (date: 11.07.2018 number: 2018/8-4).

Conflict of Interest: No conflict of interest was declared by the authors.

Financial Disclosure: The authors declared that this study has received no financial support.

Authorship Contributions: Concept - FMS, AC, MZA; Design FMS, AC, MZA; Supervision - FMS, AC, NEG, AD, MZA; Fundings - FMS, AD, NEG; Materials - FMS, AD, NEG; Data collection and/or processing - FMS, AC, MZA; Analysis and/or interpretation - MZA, $A C$; Literature review - FMS, AC, NEG, AD, MZA; Writing - FMS; Critical review - AC.

\section{REFERENCES}

1. Sieper J, Braun J, Rudwaleit M, Boonen A, Zink A. Ankylosing spondylitis: an overview. Ann Rheum Dis 2002;61 Suppl 3:iii8-18. [CrossRef]

2. Bodur H, Ataman S, Buğdaycı DS, Rezvani A, Nas K, Uzunca K, et al; Türkiye Romatizma Araştırma ve Savaş Derneği [TRASD] (Turkish League Against Rheumatism) Ankylosing Spondylitis [AS] Study Group. Description of the registry of patients with ankylosing spondylitis in Turkey: TRASD-IP. Rheumatol Int 2012;32:169-76. [CrossRef]

3. Tam LS, Gu J, Yu D. Pathogenesis of ankylosing spondylitis. Nat Rev Rheumatol 2010;6:399-405. [CrossRef]

4. Smallwood MJ, Nissim A, Knight AR, Whiteman M, Haigh R, Winyard PG. Oxidative stress in autoimmune rheumatic diseases. Free Radic Biol Med 2018;125:3-14. [CrossRef]

5. Najim RA, Sharquie KE, Abu-Raghif AR. Oxidative stress in patients with Behcet's disease: I correlation with severity and clinical parameters. J Dermatol 2007;34:308-14. [CrossRef]

6. Kozaci LD, Sari I, Alacacioglu A, Akar S, Akkoc N. Evaluation of inflammation and oxidative stress in ankylosing spondylitis: a role for mac- rophage migration inhibitory factor. Mod Rheumatol 2010;20:34-9.

7. Shah D, Mahajan N, Sah S, Nath SK, Paudyal B. Oxidative stress and its biomarkers in systemic lupus erythematosus. J Biomed Sci 2014;21:23. [CrossRef]

8. Péter I, Jagicza A, Ajtay Z, Kiss I, Németh B. Psoriasis and oxidative stress. [Article in Hu]. Orv Hetil 2016;157:1781-5. [CrossRef]

9. Gupta L, Bhattacharya S, Aggarwal A. Tenascin-C, a biomarker of disease activity in early ankylosing spondylitis. Clin Rheumatol 2018;37:1401-5. [CrossRef]

10. Biasi D, Carletto A, Caramaschi P, Bellavite P, Andrioli G, Caraffi M, et al. Neutrophil functions, spondylarthropathies and HLA-B27: a study of 43 patients. Clin Exp Rheumatol 1995;13:623-7.

11. Piva SJ, Duarte MM, Da Cruz IB, Coelho AC, Moreira AP, Tonello $\mathrm{R}$, et al. Ischemia-modified albumin as an oxidative stress biomarker in obesity. Clin Biochem 2011;44:345-7. [CrossRef]

12. Uslu AU, Kucuk A, Balta S, Ozturk C, Arslan S, Tekin L, et al. The relation between ischemia modified albumin levels and carotid intima media thickness in patients with rheumatoid arthritis. Int J Rheum Dis 2019;22:32-7. [CrossRef]

13. Türkön H, Gökmen F, Çakir DÜ, Sehitoğlu MH, Reşorlu H, Döner $\mathrm{D}$, et al. Increased Levels of Serum Ischemia Modified Albumin in Patients with Ankylosing Spondylitis. Clin Lab 2016;62:645-9. [CrossRef]

14. Rezvani A, Bodur H, Ataman S, Kaya T, Buğdaycı DS, Demir SE, et al. Correlations among enthesitis, clinical, radiographic and quality of life parameters in patients with ankylosing spondylitis. Mod Rheumatol 2014;24:651-6. [CrossRef]

15. Bar-Or D, Lau E, Winkler JV. A novel assay for cobalt-albumin binding and its potential as a marker for myocardial ischemia-a preliminary report. J Emerg Med 2000;19:311-5. [CrossRef]

16. Au YL, Wong WS, Mok MY, Chung HY, Chan E, Lau CS. Disease activity assessment in ankylosing spondylitis in a Chinese cohort: BASDAI or ASDAS? Clin Rheumatol 2014;33:1127-34. [CrossRef]

17. Henrotin YE, Bruckner P, Pujol JP. The role of reactive oxygen species in homeostasis and degradation of cartilage. Osteoarthritis Cartilage 2003;11:747-55. [CrossRef]

18. Järvinen TA, Moilanen T, Järvinen TL, Moilanen E. Nitric oxide mediates interleukin-1 induced inhibition of glycosaminoglycan synthesis in rat articular cartilage. Mediators Inflamm 1995;4:107-11. [CrossRef]

19. Altan N, Dincel A, Koca C. Diabetes mellitus and oxidative stress. Turk J Biochem 2006,31:51-6.

20. Zurawska-Płaksej E, Grzebyk E, Marciniak D, Szymańska-Chabowska A, Piwowar A. Oxidatively modified forms of albumin in patients with risk factors of metabolic syndrome. J Endocrinol Invest 2014;37:81927. [CrossRef]

21. Mehmetoğlu I, Kurban S, Yerlikaya FH, Polat H. Obesity is an independent determinant of ischemia-modified albumin. Obes Facts 2012;5:700-9. [CrossRef]

22. Aydin O, Ellidag HY, Eren E, Kurtulus F, Yaman A, Yilmaz N. Ischemia modified albumin is an indicator of oxidative stress in multiple sclerosis. Biochem Med (Zagreb) 2014;24:383-9. [CrossRef]

23. Mastella AK, Moresco RN, da Silva DB, Becker AM, Duarte MM, Giovelli LL, et al. Evaluation of ischemia-modified albumin in myocardial infarction and prostatic diseases. Biomed Pharmacother 2009;63:762-6. [CrossRef]

24. Kılıç S, Işık S, Hiz MM, Çakır DÜ, Türkön H, Cevizci S, et al. The ischemia modified albumin and mean platelet volume levels in patients with Behçet's disease. Postepy Dermatol Alergol 2016;33:345-8. [CrossRef]

25. Leitemperguer MR, Tatsch E, Kober H, De Carvalho JA, Moresco RN, Da Silva JE. Assessment of ischemia-modified albumin levels in 
patients with rheumatoid arthritis. Clin Lab 2014;60:1065-70.

26. Gökmen F, Türkön H, Akbal A. The relationship between inflammatory parameters and atherosclerosis with ischemic modified albumin levels in Sjögren syndrome. Selçuk Tip Derg 2015,31:20-3.

27. Solmaz D, Kozacı D, Sarı İ, Taylan A, Önen F, Akkoç N, et al. Oxidative stress and related factors in patients with ankylosing spondylitis. Eur J Rheumatol 2016;3:20-4. [CrossRef]

28. Wang L, Gao L, Jin D, Wang P, Yang B, Deng W, et al. The Relationship of Bone Mineral Density to Oxidant/Antioxidant Status and Inflammatory and Bone Turnover Markers in a Multicenter Cross-Sectional Study of Young Men with Ankylosing Spondylitis. Calcif Tissue Int 2015;97:12-22. [CrossRef]

29. Monti S, Todoerti M, Codullo V, Favalli EG, Biggioggero M, Becciolini A, et al. Prevalence of Ankylosing Spondylitis Disease Activity Score (ASDAS) inactive disease in a cohort of patients treated with TNFalpha inhibitors. Mod Rheumatol 2018;28:542-9. [CrossRef]

30. Altan L. Current treatment options in ankylosing spondylitis. Turk J Phys Med Rehab 2005,51:33-9.

31. Almodóvar R, Ríos V, Ocaña S, Gobbo M, Casas ML, Zarco-Montejo $\mathrm{P}$, et al. Association of biomarkers of inflammation, cartilage and bone turnover with gender, disease activity, radiological damage and sacroiliitis by magnetic resonance imaging in patients with early spondyloarthritis. Clin Rheumatol 2014;33:237-41. [CrossRef]

32. Hreggvidsdottir HS, Noordenbos T, Baeten DL. Inflammatory pathways in spondyloarthritis. Mol Immunol. 2014;57:28-37. [CrossRef]
33. Karataş Z, Baysal T, Şap F, Alp H, Mehmetoğlu I. Increased ischaemiamodified albumin is associated with inflammation in acute rheumatic fever. Cardiol Young 2014;24:430-6. [CrossRef]

34. Harman E, Sayarloglu M, Harman M, Sayarloglu $H$. The evaluation of coagulation parameters and vessel involvement in Behcet's disease. A clinical experience of Behcet's disease: study of 152 cases. Acta Med Iran 2013;51:215-23.

35. Colbert RA, Tran TM, Layh-Schmitt G. HLA-B27 misfolding and ankylosing spondylitis. Mol Immunol 2014;57:44-51. [CrossRef]

36. Sampaio-Barros PD, Conde RA, Bonfiglioli R, Bértolo MB, Samara AM. Characterization and outcome of uveitis in 350 patients with spondyloarthropathies. Rheumatol Int 2006;26:1143-6. [CrossRef]

37. Kocabaş V, Kocabaş H, Başaralı MK, Sezer I, Kaçar C,et al. The level of serum oxidant-antioxidant in patients with ankylosing spondylitis. Selçuk Üniv Tip Derg 2010,26:79-83.

38. Yazici C, Köse K, Calis M, Kuzugüden S, Kirnap M. Protein oxidation status in patients with ankylosing spondylitis. Rheumatology (Oxford) 2004;43:1235-9. [CrossRef]

39. Kageyama Y, Takahashi M, Ichikawa T, Torikai E, Nagano A. Reduction of oxidative stress marker levels by anti-TNF-alpha antibody, infliximab, in patients with rheumatoid arthritis. Clin Exp Rheumatol 2008;26:73-80.

40. Karkucak M, Capkin E, Alver A, Akyuz A, Kiris A, Ak E, et al. The effect of anti-TNF agent on oxidation status in patients with ankylosing spondylitis. Clin Rheumatol 2010;29:303-7. [CrossRef] 